Sari Pediatri, Vol. 4, No. 1, Juni 2002: 36 - 44

\title{
Senam Otak
}

\author{
Titi S.Sularyo, Setyo Handryastuti
}

\begin{abstract}
Proses belajar, berpikir, kreatifitas dan kecerdasan sesungguhnya tidak hanya melibatkan otak tetapi juga seluruh tubuh. Sensasi, gerakan, emosi dan fungsi integrasi otak semua bersumber pada tubuh kita. Oleh karena itu diperlukan suatu sistem yang bisa menghubungkan akal (mind) dan tubuh (body). Senam otak merupakan kumpulan gerakan-gerakan sederhana yang bertujuan menghubungkan atau menyatukan akal dan tubuh.
\end{abstract}

Kata kunci: hemisfer kiri, hemisfer kanan

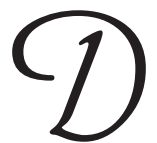

Di dunia ini, kebanyakan orang hidup dengan lebih mengandalkan hemisfer kiri, sekitar (80 - $85 \%$ ). Sebagian di antaranya memang tidak didominasi hemisfer kiri saja, tetapi campuran antara keduanya. Sisanya 15-20 persen adalah para pengguna hemisfer kanan. ${ }^{1}$ Hemisfer kiri dan kanan tersebut mempunyai spesialisasi yang berbeda-beda. Bagian hemisfer mana yang lebih banyak digunakan seseorang bisa diketahui lewat dominasi kemampuan yang mereka tunjukkan dalam kehidupan sehari-hari dalam bentuk dominasi mata, telinga, gerakan tangan dan kaki. ${ }^{1,2}$ Masing-masing hemisfer mempunyai spesifitasnya sendiri. Kedua hemisfer tersebut harus bekerja sama, teraktivasi, dan terintegrasi sepanjang waktu sehingga kita bisa mengakses semua informasi sensoris serta dapat berkomunikasi secara efektif, bergerak dan bereaksi terhadap informasi tersebut. ${ }^{2}$

Salah satu cara terbaik untuk meningkatkan integrasi kedua hemisfer tersebut adalah dengan gerakan-gerakan fisik dengan prinsip gerakan menyilang. Gerakan tersebut menggerakkan ekstremitas pada satu sisi tubuh menyilang garis tengah dan berkoordinasi dengan ekstremitas pada sisi tubuh yang lain sehingga kedua hemisfer dipergunakan pada saat

Dr. Setyo Handryastuti. Peserta Program studi IKA FKUI.

Alamat Korespondensi:

Dr. Titi Sularyo, Sp.A(K).

Staf Subbagian Tumbuh Kembang Pediatri Sosial. Bagian Ilmu Kesehatan Anak FKUI-RSCM. Jl. Salemba no. 6, Jakarta 10430.

Telepon: 021-3160622. Fax.021-3913982.

yang bersamaan. Gerakan-gerakan fisik tersebut bisa berupa senam otak, Tai Chi, Yoga, gimnastik, aerobik, berenang, ski, menyanyi, menari, bermain musik, dan lain-lain.,3 Senam otak pertama kali dikembangkan oleh Paul Dennison pada tahun 1969 untuk menolong anak-anak dan orang dewasa dengan kesulitan belajar. Sejak tahun 1987 penelitian mengenai senam otak ini telah dilakukan di seluruh dunia dengan hasil yang cukup bermakna. ${ }^{4}$

Tujuan penulisan makalah ini untuk membahas apa dan bagaimana senam otak tersebut dapat meningkatkan integrasi kedua hemisfer dan aplikasinya dalam kehidupan sehari-hari.

\section{Spesialisasi Hemisfer}

Pada proses perkembangan otak terjadi peristiwa yang disebut lateralisasi masing-masing hemisfer berkembang dan mengolah informasi dengan cara yang spesifik. Hemisfer kiri (logic hemisphere) akan menjadi pusat fungsi berbahasa, matematika, memori verbal dan analisis linear. Hemisfer kanan (gestalt hemisphere) menjadi pusat emosi, imajinasi, ritme, intuisi, visuospasial dan memori visual. ${ }^{2,5}$

Selain diferensiasi spesialisasi hemisfer, terdapat perbedaan lain di antara kedua hemisfer tersebut. Otak mempunyai pola kerja menyilang sehingga satu sisi bagian tubuh berkomunikasi dengan hemisfer otak sisi yang berlawanan. Semua fungsi sensori-motor tubuh bagian kanan diketahui dan dikontrol oleh hemisfer kiri, sedangkan fungsi sensori-motor tubuh bagian kiri 
diketahui dan dikontrol oleh hemisfer kanan. Kenyataannya, telinga kanan berkomunikasi dengan hemisfer kiri dan telinga kiri berkomunikasi dengan hemisfer kanan. Tangan kiri mengirimkan informasi kepada dan dikontrol oleh hemisfer kanan. Tangan kanan mengirimkan dan menerima sinyal dari hemisfer kiri. ${ }^{2,5}$ Kedua hemisfer tersebut dihubungkan di bagian tengah oleh sekumpulan serabut saraf yang disebut corpus callosum.

Corpus callosum diantara kedua hemisfer tersebut berfungsi sebagai sirkuit yang dapat mengakses secara cepat detil linier pada hemisfer kiri dan gambaran keseluruhan pada hemisfer kanan. Jika terdapat komunikasi yang baik di antara kedua hemisfer tersebut maka didapatkan gambaran yang terintegrasi. Makin sering kedua hemisfer tersebut dipakai akan makin teraktivasi sehingga semakin banyak koneksi terjadi melalui corpus callosum. Makin banyak koneksi, proses yang terjadi di antara kedua hemisfer semakin cepat sehingga semakin banyak fungsi intelejensi dapat kita pakai. $^{2}$

Manusia mempunyai tingkatan dominansi hemisfer. Pada keadaan tertentu seperti stres atau tahap awal dari proses belajar kita cenderung memakai hemisfer yang dominan, suatu keadaan yang disebut unilateral state. Jika kedua belah hemisfer dapat berfungsi optimal secara bersamaan maka kita akan mencapai kemampuan berpikir dan kreativitas yang tertinggi. Suatu keadaan yang disebut integrated state. Seperti telah disebutkan di atas salah satu cara untuk meningkatkan integrasi hemisfer adalah dengan gerakan-gerakan fisik, salah satunya adalah senam otak.

\section{Senam Otak}

\section{Definisi}

Senam otak merupakan kumpulan gerakan-gerakan sederhana dan bertujuan untuk menghubungkan/ menyatukan pikiran dan tubuh. Senam otak merupakan bagian dari proses edukasi kinesiologi. Kinesiologi merupakan suatu ilmu yang mempelajari gerakan tubuh dan hubungan antara otot dan postur terhadap fungsi otak. ${ }^{6,7}$ Gerakan-gerakan tertentu diyakini penting untuk perkembangan otak manusia, sebagai contoh gerakan merangkak pada bayi akan mengembangkan koneksi diantara kedua belah hemisfer. Gerakan ini kemudian dikembangkan menjadi gerakan yang lebih kompleks untuk meningkatkan proses belajar dan memaksimalkan kemampuan individu. ${ }^{6}$

\section{Cara kerja}

Seperti telah disebutkan sebelumnya, agar kedua hemisfer bisa bekerja efektif maka kedua belah hemisfer tersebut harus difungsikan secara simultan. Ketika kita berada dalam keadaan stres, otak bereaksi dengan menghambat transmisi informasi yang bersifat simultan. Salah satu hemisfer akan switched off, dari sinilah berbagai problem akan timbul. Akan terjadi masalah dalam koordinasi dan gangguan terhadap kemampuan untuk berpikir jernih, memecahkan masalah, kemampuan komprehensi, organisasi dan komunikasi secara efektif. ${ }^{6}$ Dalam hal ini senam otak dapat mengakses kedua hemisfer secara simultan, hemisfer akan kembali switched on dan berada dalam kondisi terintegrasi.

Kita telah mengetahui bahwa otak mengontrol semua fungsi tubuh, senam otak memanfaatkan dan membentuk relasi diantara otak dan tubuh, Dengan melakukan gerakan-gerakan untuk mengakses otak ternyata kita dapat mengintegrasikan semua area yang berhubungan dalam proses belajar sehingga kita dapat meningkatkan kemampuan untuk memaksimalkan kedua belah hemisfer dan memperbaiki penampilan. ${ }^{7}$ Senam otak membantu mengintegrasikan:

1. Batang otak/ brain stem ( fungsi pernapasan, homeostasis dan tendon guard reflex)

2. Otak tengah/mid brain (sistem limbik, kontrol suhu, memori, emosi, kelenjar dan kimia tubuh serta fight/flight response)

3. Neo cortex (kemampuan berpikir yang tertinggi, komunikasi, hemisfer kiri dan kanan) ${ }^{6}$

Dalam keadaan stres, batang otak adalah fokus aktifitas otak dan berfungsi untuk survival (tendon guard reflex) bila kita menghadapi bahaya. Refleks ini bisa terkunci/ terhambat oleh lingkungan dan stres emosi seperti tekanan pekerjaan, ujian serta menghambat akses ke memori (sistem limbik) dan kemampuan berpikir (neo-cortex). Senam otak dapat memperbaiki kemampuan semua area otak dengan cara mengaktivasi semua fungsi. ${ }^{6}$

\section{Manfaat senam otak}

Senam otak untuk anak dan dewasa dilakukan untuk memperbaiki ${ }^{6}$ :

- Kemampuan membaca, mengeja, komprehensi, 
menulis tangan dan membuat tulisan.

- Kepercayaan diri, koordinasi dan komunikasi.

- Konsentrasi dan memori.

- Hiperaktifitas.

- Mengatasi stres dan mencapai suatu tujuan.

- Motivasi dan mengembangkan kepribadian.

- Ketrampilan organisasai.

- Penampilan.

\section{Gerakan-gerakan senam otak ${ }^{4,7,8}$}

\section{Cross crawl (gerak diagonal)}

Meningkatkan komunikasi dan intergrasi di antara kedua hemisfer serebri dengan terbentuknya percabangan dan mielinisasi persarafan di corpus callosum sehingga komunikasi antara kedua hemisfer bertambah cepat dan lebih terintegrasi. Gerakan ini meningkatkan koordinasi penglihatan, pendengaran, kemampuan kinestetik sehingga meningkatkan kemampuan mendengar, membaca, menulis dan daya ingat. Koordinasikan gerakan supaya kalau satu tangan bergerak, kaki yang berlawanan bergerak pada saat yang sama. Gerakkan badan ke depan, ke samping, ke belakang dan arahkan mata kesemua jurusan. (Gambar 1)
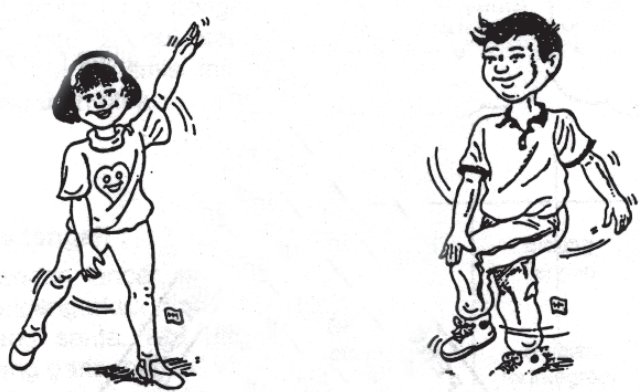

Gambar 1. Cross crawl (gerak diagonal)

\section{Alphabet 8s (abjad 8)}

Memadukan gerakan-gerakan yang terlibat dalam pembentukan huruf. Gerakan ini mampu membuat anak untuk menulis lebih otomatis dan memacu otak untuk berpikir kreatif. (Gambar 2)

\section{Double doodle (menggambar dua tangan)}

Melukis dengan 2 tangan sebelah menyebelah akan membangkitkan keterarahan dan orientasi ruang,

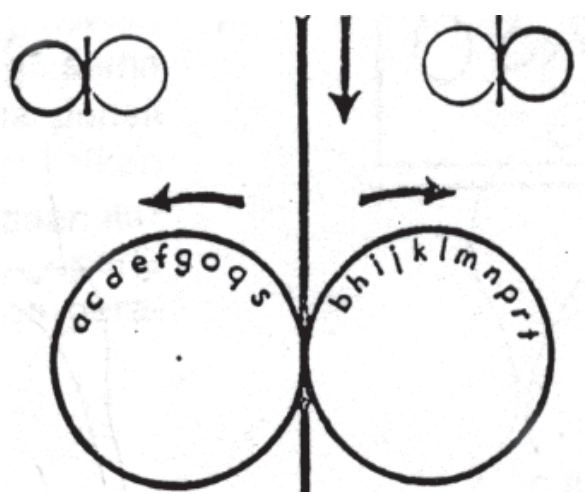

Gambar 2. Alphabet 8s (abjad 8)

karena terkait dengan garis tengah tubuh. Kegiatan ini melatih kemampuan kedua mata secara bersamaan dan membantu pengembangan koordinasi tangan 2 mata untuk meningkatkan ketrampilan menulis.

Menggambar dengan kedua tangan pada saat yang sama ke dalam, ke luar, ke atas dan ke bawah. (Gambar 3)

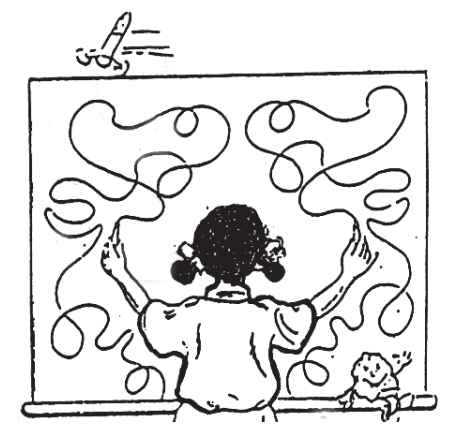

Gambar 3. Double doodle (menggambar dua tangan)

\section{Lazy 8 (8 malas)}

Memadukan bidang penglihatan kiri dan kanan sehingga meningkatkan integrasi otak kiri dan kanan sekaligus meningkatkan keseimbangan dan koordinasi tubuh. Gerakan ini dapat meningkatkan ketrampilan baca tulis \& pemahaman.

Mulai di bagian tengah, pertama gerakkan tangan berlawanan arah jarum jam: ke atas, membentuk lingkaran. Kemudian searah jarum jam: ke atas, membentuk lingkaran dan kembali ke titik tengah.

Buatlah gerakan ini 3 kali tiap tangan, kemudian 3 kali dengan kedua tangan. Gambar 4 


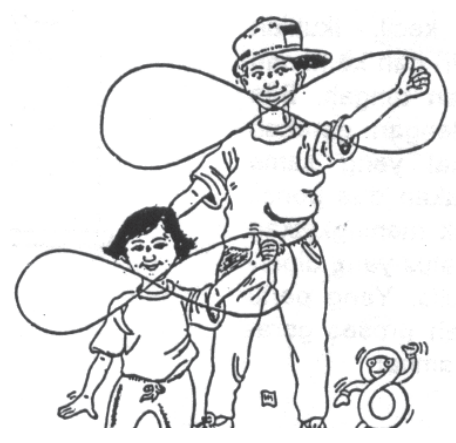

Gambar 4. Lazy 8 (8 malas)

\section{Belly breathing (pernapasan perut)}

Meningkatkan persediaan oksigen untuk seluruh tubuh, terlebih untuk otak. Kegiatan ini merelakskan SSP sambil meningkatkan kadar energi, Gerakan ini terbukti meningkatkan kemampuan membaca dan berbicara.

Taruh tangan di perut. Buang napas pendekpendek, lalu ambil napas dalam dan pelan-pelan. Tangan mengikuti gerakan perut waktu membuang dan mengambil napas.

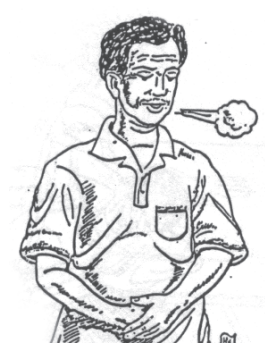

Gambar 5. Belly breathing (pernapasan perut)

\section{The elephant (gajah)}

Gerakan ini mengaktifkan dan menyeimbangkan semua sistem pada tubuh dan pikiran kita. Mengaktivasi sistem vestibuler terutama kanalis semisirkularis demikian juga koordinasi tangan dan mata. Gerakan ini memadukan sisi kiri dan kanan otak untuk penglihatan, pemahaman, pendengaran, memori jangka pendek/panjang dan berpikir abstrak.

Tekuk lutut sedikit, lekatkan kepala kebahu dan tangan lurus kedepan. Gunakan tulang dada untuk menggerakkan seluruh badan atas membuat gerakan Lazy 8 . Lihat ke jari anda dan ulangi dengan tangan satunya.

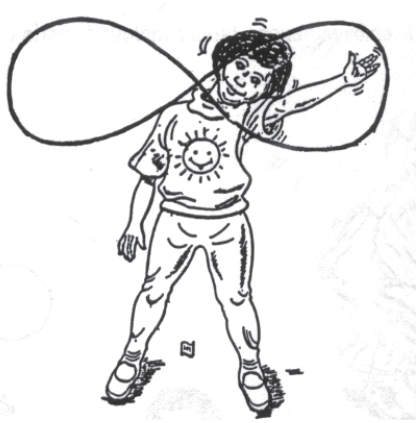

Gambar 6. The elephant (gajah)

\section{Neck rolls (putar kepala)}

Gerakan ini mampu menurunkan tegangan otot leher, meningkatkan kemampuan melaksanakan kegiatan mental tanpa tekanan. Gerakan ini meningkatkan pernapasan dan relaksasi titik-titik vokal untuk pembicaraan yang lebih beresonansi. Karena ada peningkatan di dalam kemampuan menggerakkan mata dari kiri ke kanan melewati bidang tengah penglihatan, maka kemampuan baca juga meningkat.

Tundukkan kepala kedepan, dan pelan-pelan putar dari satu sisi kesisi lainnya. Tengadahkan kepala kebelakang, dan putar lagi kekiri kekanan. Ulangi dengan bahu diturunkan.
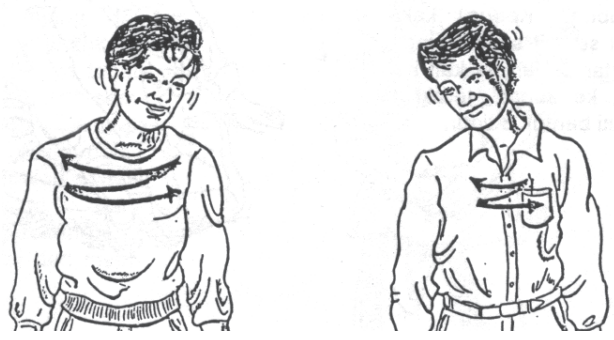

Gambar 7. Neck rolls (putar kepala )

\section{The rocker (pompa bokong)}

Gerakan ini mengurut lengan \& paha, membantu menurunkan tegangan otot di bagian belakang tubuh 
yang menghalangi anda bergerak ke depan dengan mudah. Meningkatkan aliran cairan serebrospinal ke otak, jadi meningkatkan kemampuan untuk fokus, konsentrasi dan pemahaman.

Duduk di lantai, tangan ditaruh di belakang, ditekuk, ke 2 kaki diangkat sedikit, dan gerakkan pinggul memutar beberapa kali sampai rileks.

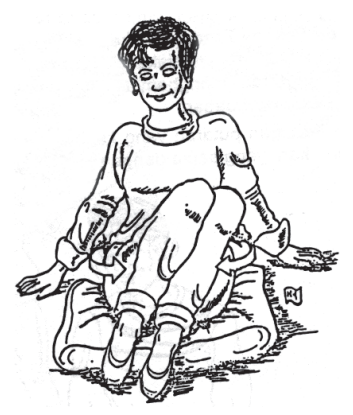

Gambar 8. The rocker (pompa bokong)

\section{Cross crawl sit-up (gerak diagonal telentang)}

Gerakan ini mengaktifkan kedua belahan otak secara serempak. Ia menggabungkan otak untuk koordinasi penglihatan, pendengaran dan kemampuan kinestetik. Jadi meningkatkan kemampuan mendengar, membaca, menulis dan daya ingat.

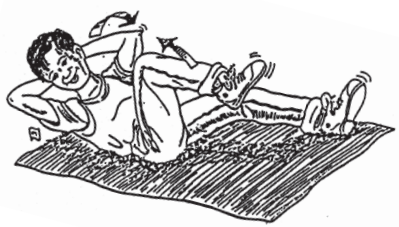

Gambar 9. Cross crawl sit-up (gerak diagonal telentang)

\section{Energizer (kepala kobra)}

Gerakan ini terdiri dari menarik napas panjang dan dalam sehingga meningkatkan oksigenasi, relaksasi otot leher dan bahu. Gerakan ini membangkitkan sistem terutama setelah bekerja di depan komputer dan duduk dalam waktu yang lama. Dapat memperbaiki postur, konsentrasi \& perhatian, secara khusus berguna selama kita bekerja di depan komputer.

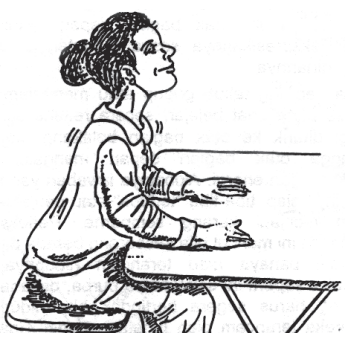

\section{Gambar 10 Energizer (kepala kobra)}

\section{The owl (burung hantu)}

Kegiatan ini menurunkan tegangan otot bahu $\&$ leher. Pada saat otot leher rileks kemampuan mendengar, berpikir dan berbicara meningkat.

Cengkeram otot bahu, gerakkan kepala menengok ke belakang, tarik napas dalam dan tarik bahu ke belakang, kemudian menengok kesisi yang lain. Tundukkan kepala, napas dalam, biarkan otot relaks. Ulangi dengan mencengkeram bahu yang lain.

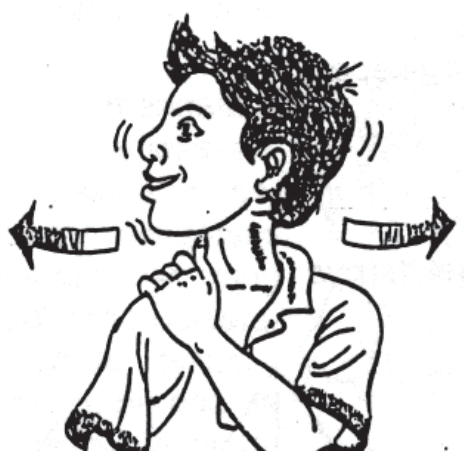

Gambar 11. The owl (burung hantu)

\section{Arm activation (mengaktifkan tangan)}

Gerakan ini meregangkan otot bahu \& dada atas. Gerakan ini merilekskan \& mengkoordinasi otot-otot bahu dan lengan serta membantu otak dalam kemudahan menulis dengan tangan, mengucap dan menulis kreatif.

Luruskan satu tangan ke atas, ke samping kuping. Buang napas pelan, sementara otot-otot diaktifkan dengan mendorong tangan melawan tangan satunya keempat jurusan (depan, belakang, ke dalam dan keluar) 


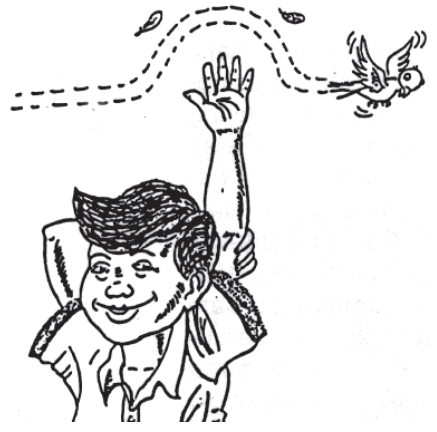

Gambar 12. Arm activation (mengaktifkan tangan)

\section{The footflex (melenturkan sendi kaki)}

Gerakan ini mengembalikan ukuran panjang alamiah sendi-sendi bagian belakang kaki. Gerakan ini akan merelakskan reflkesi untuk bertahan sekaligus meningkatkan kemampuan komunikasi, konsentrasi dan menyelesaikan pekerjaan.

Cengkeram tempat-tempat yang terasa sakit di pergelangan kaki., betis dan belakang lutut satu persatu, sementara pelan-pelan kaki digerakkan ke luar dan ke dalam.

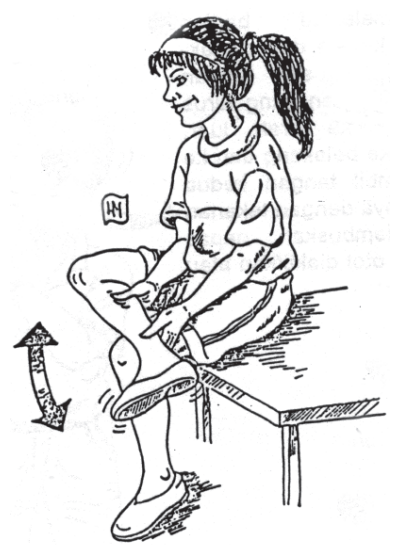

Gambar 13. The footflex (melenturkan sendi kaki)

\section{Calf pump (pompa betis)}

Gerakan ini menghasilkan kekuatan yang lebih alamiah bagi otot $\&$ tulang di bagian belakang tubuh. Kegiatan ini mempermudah refleks bertahan $\&$ membebaskan perasaan-perasaan yang membuat kita tidak mampu ikut serta dalam melakukan kegiatan yang positif.
Pompa ini meningkatkan konsentrasi perhatian, pemahaman yang mendalam \& kemampuan untuk mengerjakan sesuatu sampai selesai.

Waktu anda memajukan badan ke depan \& buang napas, pelan-pelan tekan telapak kaki kebelakang lantai, kemudian angkat ke atas sambil ambil napas dalam. Ulangi 3x tiap kaki.

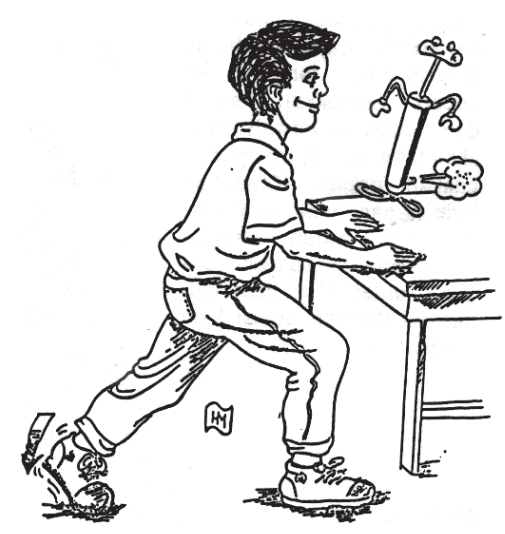

Gambar 14. Calf pump (pompa betis)

\section{The gravity glider (bandul gravitasi)}

Gerakan ini merelakskan kelompok otot, ini penting untuk keseimbangan dan koordinasi seluruh tubuh dan membantu pemahaman.

Silangkan kaki, lutut tetap relaks. Tundukkan badan ke depan dengan tangan lurus, buang napas waktu turun, dan ambil napas waktu naik. Ulangi $3 \mathrm{x}$, kemudian ganti kaki.

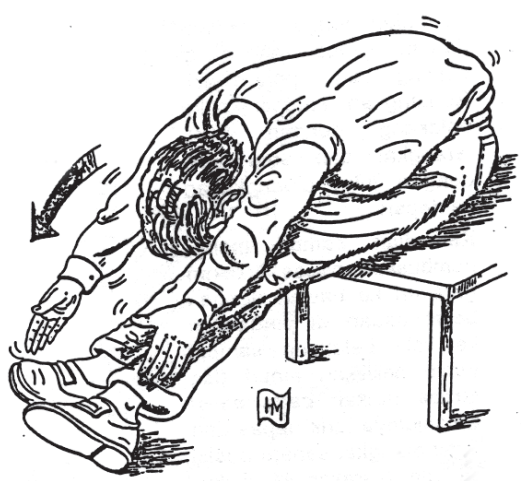

Gambar 15. The gravity glider (bandul gravitasi) 


\section{The grounder (kuda-kuda)}

Kegiatan ini memperlancar dan merilekskan kelompok otot di paha yang menyeimbangkan dan menstabilkan tubuh. Melakukan gerakan ini dapat meningkatkan pemahaman, memori jangka pendek, ekspresi \& ketrampilan organisasi.

Mulai dengan kaki terbuka, arahkan kaki kanan ke kanan, dan kaki kiri tetap lurus kedepan. Tekuk lutut kanan sambil buang napas, lalu ambil napas waktu lutut kanan diluruskan kembali. Ulangi $3 \mathrm{x}$, kemudian ganti dengan kaki kiri.

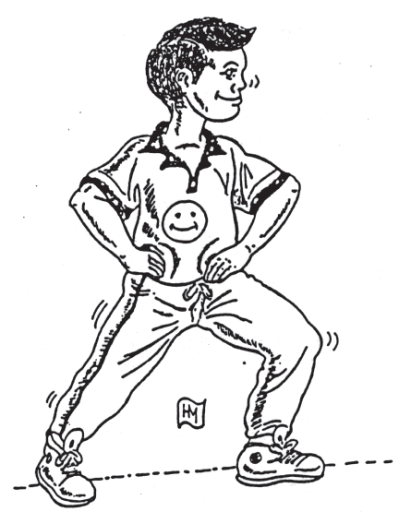

Gambar 16. The grounder (kuda-kuda)

\section{Brain buttons (tombol otak)}

Kegiatan ini merangsang aliran darah yang kaya oksigen melalui arteri karotis ke otak. Tombol ini membantu membentuk kembali pesan-pesan yang terarah dari bagian tubuh ke otak dan penglihatan, jadi meningkatkan hubungan silang antara otak untuk membaca, menulis, berbicara dan mengikuti petunjuk.

Sambil menyentuh pusar, pijat keras sisi kiri dan kanan tulang tengah (sternum) di bawah tulang dada.

\section{Earth buttons (tombol bumi)}

Menyentuh tempat-tempat ini merangsang otak $\&$ menyegarkan kembali kelelahan mental yang berat, mampu meningkatkan ketrampilan organisasional \& meningkatkan kemampuan untuk terfokus pada objek yang dekat.

Taruh 2 jari di bawah bibir dan tangan yang satu di os. pubis. Napaskan energi ke atas, ke tengah-tengah badan.

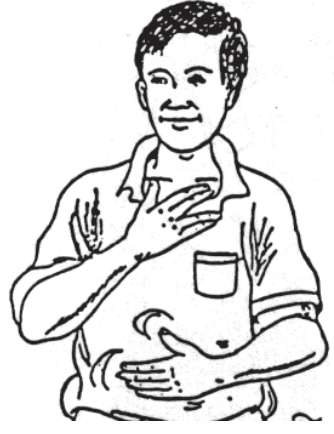

Gambar 17. Brain buttons (tombol otak)

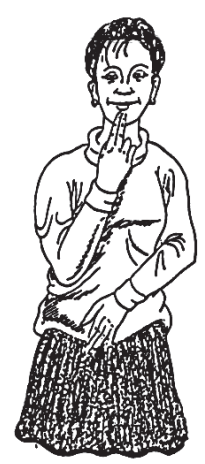

Gambar 18. Earth buttons (tombol bumi)

\section{Space buttons (tombol ruang)}

Menekan 2 titik ini merangsang gerakan seluruh sistem yang meningkatkan perhatian, fokus, motivasi dan intuisi pengambilan keputusan.

Taruh 2 jari di atas bibir dan tangan satunya di tulang ekor selama 1 menit, napaskan energi keatas tulang punggung.

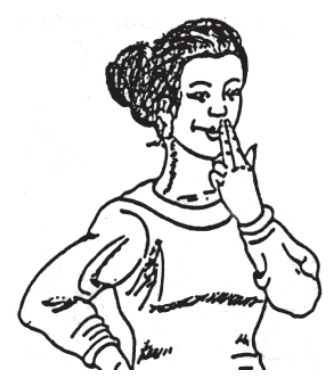

Gambar 19. Space buttons (tombol ruang) 


\section{The thinking cap (pijat kuping)}

Kegiatan ini membangkitkan mekanisme pendengaran dan memori. Sehingga meningkatkan kemampuan mendengar, memori jangka pendek dan ketrampilan berpikir abstrak.

Pelan-pelan buka daun kuping keluar, $3 \mathrm{x}$ dari atas ke bawah.

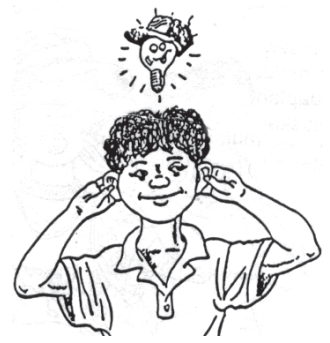

Gambar 20. The thinking cap (pijat kuping)

\section{Balance button (tombol keseimbangan)}

Kegiatan ini merangsang sistem keseimbangan tubuh di telinga bagian dalam. Gerakan ini akan memperbaiki keseimbangan, merilekskan mata dan bagian lain tubuh anda serta mempermudah perhatian anda untuk berpikir dan melakukan kegiatan. Pengambilan keputusan, konsentrasi dan pemecahan masalah semuanya akan meningkat pada saat organisasi tubuh meningkat.

Sentuhkan 2 jari ke belakang telinga dan taruh tangan satunya di pusar. Napaskan enersi keatas, setelah 1 menit sentuh belakang telinga yang lain.

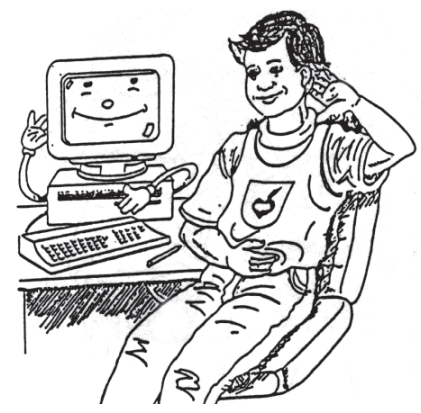

Gambar 21. Balance button (tombol keseimbangan)

\section{The energy yawn (pijat otot menguap)}

Lebih dari 50\% hubungan syaraf dari otak ke bagian lain tubuh berjalan lewat persambungan rahang.
Mengurut-urut bagian otot yang menggerakkan mulut untuk buka tutup merelakskan rahang, memperlancar hubungan-hubungan syaraf untuk peningkatan otak secara keseluruhan..

Taruh jari di rahang yang terasa tegang. Buat suara menguap lebar dan relaks, sambil memijat pelan untuk melepas ketegangan.

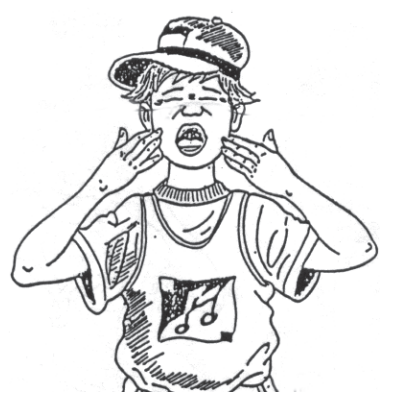

Gambar 22. The energy yawn (pijat otot menguap)

\section{Cook's hook up (duduk angkat kaki jari bersentuhan)}

Kegiatan ini menyeimbangkan dan menghubungkan dua hemisfer. Kegiatan ini memperkuat energi elektris tubuh, terlebih dalam situasi yang penuh tekanan dan tidak biasa seperti pada saat bekerja dengan komputer, TV, AC.

Pertama, taruh menyilang kaki kiri di atas paha kanan atau sebaliknya. Lalu tangan kanan memegang pergelangan kiri dan tangan kiri pada telapak bawah kaki kanan. Kedua, turunkan kaki, satukan kedua tangan sambil terus napas dalam selama 1 menit lagi.

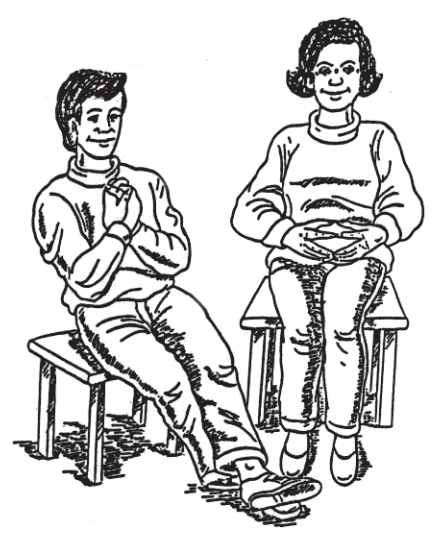

Gambar 23. Cook's hook up (duduk angkat kaki jari bersentuhan) 
Sari Pediatri, Vol. 4, No. 1, Juni 2002

\section{Positive points (titik positif)}

Titik positif adalah titik-titik tekanan di dahi yang khusus diketahui untuk refleks menghadapi sesuatu atau lari dari sesuatu, jadi menurunkan tekanan stres emosional. Sentuh perlahan the positive points, dua tonjolan di dahi.

Aplikasi gerakan-gerakan senam otak dalam kehidupan sehari-hari tergantung dari kebutuhan seseorang. Misalnya dalam pekerjaan akuntansi yang memerlu-kan kemampuan matematis, maka gerakangerakan senam otak adalah tombol bumi, tombol ruang, tombol keseimbangan, pijat kuping, burung hantu dan pijat otot menguap.

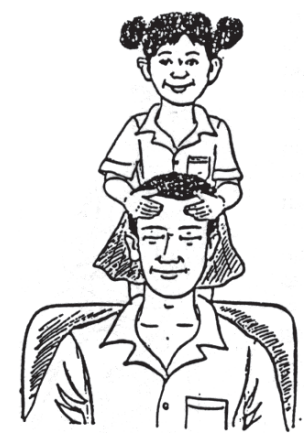

Gambar 24. Positive points (titik positif)

\section{Daftar Pustaka}

1. Munir R, Nilawati S. Senam otak, mudah dilakukan, banyak kegunaan. Kompas 4 Februari 2001;14.

2. Hannaford C. The dominance factor, how knowing your dominant eye, ear, brain, hand $\&$ foot can improve your learning. Arlington: Great Ocean Publishers, 1997. h. 15-34.

3. Hannaford C. The dominance factor, how knowing your dominant eye, ear, brain, hand\&foot can improve your learning. Arlington: Great Ocean Publishers, 1997. h. 116-23.

4. Hannaford C. Smart moves, why learning is not all in your head. Arlington: Great Ocean Publishers, 1995. h. 108-31.

5. Kusumoputro S, Sidiarto L, Markam S. Perkembangan fungsi kortikal luhur dalam klinik kedokteran. Dalam: Kusumoputro S, penyunting. Neurologi klinik. Jakarta: Bagian Neurologi FKUI/RSCM, 1986. h. 19-23.

6. What is brain gym ?. Brain gym.htm.

7. Carrigan C. Brain gym ${ }^{\mathrm{TM}}$ with educational kinesiology consultant. http://total fitness.net/brain_gym.html.

8. Winkelmann P. Brain Gym: Kumpulan latihan sederhana untuk diterapkan di kelas dan di tempat kerja. Disampaikan pada pelatihan Brain Gym, Ruteng, Maret 1997.

9. Dennison PE, Dennison GE. Personalized whole brain integration. Edu-Kinesthetics, Inc, 1985. h. 59-62. 